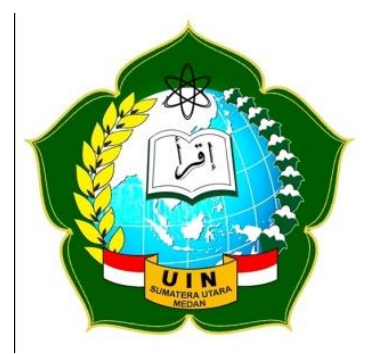

VISION JOURNAL

http://jurnaltarbiyah.uinsu.ac.id/vision

\title{
INDONESIAN EFL TEACHERS' PERSPECTIVE ON GOVERNMENT PROFESSIONAL DEVELOPMENT PROGRAM
}

Diah Safithri Armin

Department of English Education, UINSU

Email: diahsafithriarmin@uinsu.ac.id

\begin{tabular}{|c|c|}
\hline Keywords & Abstract \\
\hline $\begin{array}{l}\text { Keywords: Government } \\
\text { Professional Development } \\
\text { Programs, Indonesian EFL } \\
\text { Teachers, KKG, MGMP, PKG, } \\
\text { Professional Development }\end{array}$ & $\begin{array}{l}\text { Indonesian government provides many programs in } \\
\text { developing teacher's profession, such as certification, } \\
\text { standard of education background, and teachers' group } \\
\text { (Teacher Activity Center (PKG), Course Teacher Forum } \\
\text { (MGMP), and Teacher Working Group (KKG)). This study } \\
\text { attempted to investigate teachers' perspective on government } \\
\text { professional development programs. This research applied } \\
\text { basic interpretive qualitative research, and used open-ended } \\
\text { questionnaire and semi structured interview as technique of } \\
\text { collecting data. The participants of this research were fifty } \\
\text { EFL teachers from five cities in Indonesia. The research } \\
\text { finding showed that Indonesian EFL teachers have positive } \\
\text { perspective on professional development in improving their } \\
\text { teaching skill. Most of the EFL teachers also have positive } \\
\text { perspective on government professional development } \\
\text { programs, even though some of them suggest that the } \\
\text { government professional development program is better to } \\
\text { provide activities improving their teaching skills than to } \\
\text { discuss administration. The implication of this study is the } \\
\text { Indonesian EFL teachers have positive perspective on } \\
\text { government professional development programs, but they also } \\
\text { suggest the government professional development programs } \\
\text { should focus on helping the teacher in improving their } \\
\text { teaching skills. }\end{array}$ \\
\hline
\end{tabular}

Faculty of Tarbiyah and Teacher Training, 1st Floor

Jalan Willem Iskandar Psr V Medan, 20731

Telp. 061- 6622925 - Fax. 061 - 6615685 


\section{INTRODUCTION}

As the member of some global computation, such as World Trade Organization (WTO), Association of Southeast Asian Nations (ASEAN), Asia-Pacific Economic Cooperation (APEC), and ASEAN Free Trade Area (AFTA), Indonesian people are indirectly required to mater English. To overcome this condition, Indonesian Government includes English as one of compulsory course in the current curriculum which is taught from Junior High School as stated in Permendikbud No. 68 Year 2013. Besides, the government also sets some standard competences which are obligated to be gained by the teachers in Permendikbud No. 16 Year 2007. They are pedagogic competence, personality competence, social competence, and professional competence. To achieve these standards, especially professional competence, the government provides some professional development programs to support the EFL teachers in improving their teaching skills: having academic qualification, teachers' activity such as Teacher Activity Center (PKG), Course Teacher Forum (MGMP), Teacher Working Group (KKG) (UU RI No. 14 year 2005), and certification (Permendikbud, 2013).

In one informal group discussion about current issue on teaching English in Indonesia with some EFL teachers, one of the members stated that if the government professional development programs do not work efficiently. The participants of the programs seem excited in implementing their knowledge gained from the training in two or three weeks, then they back to their daily teaching techniques. It was also found by Sheppard (cited in Sheppard et al., 2009, p.86) in one of province in Canadian that $28 \%$ of teachers perceived that professional development experiences wasted time and $38 \%$ of them argued that it did not relevant to their needs. This issue led the researcher to conduct the present study. Besides, measuring the teachers' success in teaching becomes the key and policy issue during past decade (Kane \& Cantrell, 2010). In addition, most researches on professional development discuss professional development and continuous learning (e.g. Avalos, 2011; Clandinin et al., 2013; Hargreaves, 2013; Russ, Sherin, \& Sherin, 2016), continuing professional development (e.g. Banilower, Heck, \& Weiss, 2007; Garet, Porter, Desimore, Birman, \& Yoon, 2001; Heck, Banilower, Weiss, \& Rosenberg, 2008; Tabatabaee-Yazdi, Motallebzadeh, Ashraf, \& Baghaei, 2018) and etc., but only few researches have discussed the effectiveness of government professional development program. Therefore, the present study was conducted to find the Indonesian EFL teachers' perspective on government professional development programs by focusing on 1) EFL teacher's perspective on 
professional development, and 2) EFL teachers' perspective on government professional development programs.

The significance of this study is as an information for educators, EFL teachers, novice teachers, other researchers, as well as reflection for Education Ministry as the policy makers.

\section{LITERATURE REVIEW}

\section{Professional Development}

Teaching as a process of learning particular thing has three main characteristics: lecturing, transferring knowledge, and facilitating the students in the learning process (Mohanan, 2005) yet the most important in teaching is promoting and facilitating the students in learning autonomously (Dornyei and Murphy cited in Harmer, 2007). Some factors can influence the success of this teaching process, such as the level of instructional resources available, staffing levels, administrators and parents support, and continuing professional development (Johnson cited in Mitchell et al, 2001, p. 19). Consequently, the teachers need to develop themselves not only in their teaching skills, but also in knowledge, vision, even review their teaching beliefs (Day, 2002; McNamara, 2002) since teaching belief impacts their teaching instruction and decision (Vries, Grift, \& Jansen, 2012). Likewise, the point of development is the teacher's personal and profession in school (Day, 2002). Thus, developing teacher's self is an important component in education reform (Hall \& Hord, 2006, p. 7).

Further, the teacher cannot merely relay on their experience in developing their professionalism as long as being professional does not only needs to improve knowledge and skill, but also needs many experiences even extensive study due to concerning in some performance with specific function in some degree of expertise and using mental of thinking (Danim, 2011; Ur, 2002), so to be professional, the teacher needs to be ongoing learning (Chatib, 2009, p. 148). Professional teacher are required to have specific characteristics, such as having intellectual knowledge which could be gained through education, being a member of profession organization, having work strategies, having capability of self-organization, understanding students' psychology development, desiring to update knowledge, acting as the facilitator in teaching process, being energic, innovative, patient, objective, and optimistic, being able to make quick decision, having salary system, attending annual professional meeting, and producing works (Sujanto, 2007; Thompson, 2007, p. 7; Khalifah \& Khutub, 2009; Danim, 2011; Rugaiyah \& Sismiati, 2011). 
Many professional development activities the teachers can do, such as reading, peer coaching, peer observation, teacher support group, attending workshop, self-monitoring, keep a teaching journal, team teaching or pair teaching, teaching portfolio, and action research. Gebhard (2009) explains that to improve knowledge and teaching practice, the EFL teacher can read educational journals and books.

Peer coaching also known as peer mentoring and reciprocal activity refers to a giving feedback activity from observer to the teacher and sharing idea each other as a reflection to improve their teaching practices and this activity can be done formally and informally (Brown, 2001; Richards and Thomas, 2005). Commonly, the observer in this activity is an experience teacher, while the observed teacher is novice teacher (Murray \& Christison, 2011).

Peer observation is conducted by observing other's teaching practice to get knowledge, teaching technique idea, class behaviour, and class interaction, but not for judging. Teacher can use memo and sketch or videotape the class activity (Gebhard, 2009; Harmer, 2007; Richard and Thomas, 2005; Nunan, 1996). However, generally, a teacher dislike being observed by others (Brown, 2001; Nunan, 1996; Richards and Thomas, 2005).

Teacher support group is group in which the teacher can share and discuss their experience, concern, goals, and problems (Brown, 2001; Richards and Thomas, 2005). This group can be team teaching, peer coaching, actin research, and classroom observation utilized to achieve individual and shared goals.

Attending workshop can improve teachers' specific knowledge and skill since a workshop is leaded by the expert of the workshop topic. By attending workshop, the teacher not only gain knowledge, but also can examine their teaching beliefs as well as reflect their teaching practice (Richards and Thomas, 2005). Commonly, the teachers prefer attending workshop as the most useful professional development activity (Richard, Gallo, \& Renandya in Richards and Thomas (2005).

Self-monitoring refers to self-observation through lesson report, audio-record or videorecord (Brown, 2001; Nunan, 1996; Richards and Thomas, 2005). This activity provide the information about teacher's teaching strength and weakness.

Teaching journal is a media for teachers to record their teaching practice, teaching beliefs, and their thinking (Richard and Thomas, 2005). This record reflects whether the teaching is successful or unsuccessful. Besides, this journal can be used for classroom observation, discussion, and teaching ideas (Gebhard, 2009). Thus, Keeping a teaching 
journal can help the teacher to reflect their teaching and revise their teaching practice as an effort of improving their professionalism.

Team teaching or also known as pair teaching refers to group consist of two teachers or more who share equal teaching responsibility included planning a course, doing assessment or evaluation in same class (Brown, 2001; Nunan, 1996; Richards and Thomas, 2005). This activity helps the teacher to handle the class activities which cannot be handle by one teacher, promotes collegiality, combine their knowledge and ideas, gives feedback, as well as observes each other in order to know their strength and weakness in teaching (Brown, 2001; Nunan, 1996; Richards and Thomas, 2005).

Teaching portfolios refers to a bundle of documents and other item used to inform the teachers' work from different aspect. The document are chosen to serve a basis self-appraisal and component of teacher's assessment (Richards and Thomas, 2005).

Last, action research is a research done by a teacher to solve the learning problem to improve their teaching practice (Brown, 2001; Nunan, 1996; Richards and Thomas, 2005). Action research can be conducted formally and informally with four procedures, planning, action, collecting data, and interpretation.

The teachers have a positive perspective on professional development which could be seen from their attitudes (Noordewir, Korthagen, \& Zwart, 2009) in terms of interest, confidence and enjoyment on professional (Lee, Karen, Jaime, Scott, Constance, \& Kathryn, 2008) and on the research that was conducted in Gaza, the most common strategy of professional development that done by teachers was action research continually (Shoqair and Shaaban, 2013).

\section{Government Professional Development Program}

Professional development is teacher's responsibility as well as school and government (Day, 2002), because teacher's professional development impact the school quality (Hoque et al., 2011). Indonesian government provides three programs as professional development activities for teachers: 1) Have academic qualification, at least undergraduate, which is cited in UU RI No. 14 year 2005; 2) Certification in which the teachers are trained and educated by pointed university, and the teachers are given a certificate if the pass the certification test. If the teachers have this certificate, then they will be given additional fee called teacher certification fee; 3) teachers activities such as Teacher Activity Center (PKG), Course Teacher Forum (MGMP), Teacher Working Group (KKG) which is cited in UU RI No. 14 
year 2005. PKG, MGMP, and KKG is the media for the teachers to exchange their teaching experiences as well as discussing their teaching problems.

Mustofa (2007) points out that the government increases the qualification and education requirements for being a teacher such as undergraduate. Then, the government provides certification for teachers who pass the examination after educating and training by giving education certification and more fees. And the government also create a teachers' group such Teacher Activity Center (PKG), Course Teacher Forum (MGMP), Teacher Working Group (KKG) where teachers can share their teaching problems.

A research by Suwarno (2009) found that PKG is important in improving teacher' professionalism. In PKG, the teachers are taught about teaching innovation, new issue in teaching, how to arrange lesson plan, how to evaluate the students, etc. PKG can be a solution for the teachers who seldom attend or participate in workshop or training.

Purnomo (2015) found that MGMP has positive and significant correlation with EFL teacher's professionalism which is proven by $t_{\text {count }}(24,32)$ is higher that $t_{\text {table }}(2,17)$. In means that MGMP can improve the teacher's professionalism.

\section{METHOD}

The participant of the study were fifty EFL teachers in Primary, Junior, and Senior High school from five cities in Indonesia.

The present study applied basic interpretative qualitative study. The basic interpretive qualitative study is

"to discover and understand a phenomenon, a process, the perspectives and worldview of the people involved, or a combination of these. Data are collected through interview, observations, or document analysis". (Merriam, 2002, p. 6)

The present study used open-ended questionnaire and semi-structured interview as the techniques of data collection due to limited time and opportunity to meet the EFL teachers. Open-ended questionnaire gives an opportunity to the participants to give more personal comment (McDonough \& McDonough, 2006) and interview gives an opportunity to know participant's attitude, interest, feelings, concerns, and values (Malik \& Hamied, 2014, p. 212). Semi structured interview is a flexible interview that gives an opportunity to the researcher to the order of the question and be more extensive on interviewee's response ((McDonough \& McDonough, 2006), p. 183). 
Some procedures were done in analyzing the data, namely data reduction, data display, and drawing conclusions (Alwasilah, 2009). The data from the questionnaire would be coded first, reduce the inappropriate data, and then analyzed descriptively. And the data from semi-structured interview would be transcribed first, reduce the inappropriate data, and then would be analyzed by describing and interpreting.

\section{FINDING AND DISCUSSION}

Based on the data analysis, most of the participants define professional teachers as a teacher who have personal competence, social competence, pedagogical competence also professional competence. In addition, the teachers argue that the teachers obligate to have not only these four competences, but also emotional competence, cultural competence, multiple intelligent, many experiences, and know their role and obligation in teaching. However, all participants agree that a professional teacher must not join any teacher group. This result is in line to what Danim (2011), Khalifah \& Khutub (2009), Rugaiyah \& Sismiati (2011), Sujanto (2007), and Thompson (2007, p. 7) found in their studies that the teachers disagree if a professional teacher should join any group teacher.

One of the participant argue that teaching is about teaching itself, not ranging lesson plan. This argument is opposite the characteristics of professional teacher by Sujanto (2007), Thompson (2007, p. 7), Khalifah \& Khutub (2009), Danim (2011), and Rugaiyah \& Sismiati (2011) which say that teacher should be able to arrange a lesson plan well and detail.

According to the participants, professional development is important because when the teachers develop their professionalism means they update their knowledge about teaching and current issues, teaching methods and strategies. Developing their personalism does not only help the teacher to improve the learning quality, but also help them to improve their career. This argument is in line with Day (2002) and McNamara (2002) argument that the improving teachers professionalism is important since it obligates the teachers to update their knowledge, skill, and vision, as well as reflect and examine their teaching beliefs.

To improve their professionalism, the participants do many activities, such as attending workshop and seminar, joining teacher training, reading educational journals and books, discussing with colleagues, writing teaching journal, doing teaching reflection even continuing study in university. Especially for English teachers in primary school, they choose to join the English debate group and trainings that are provided by their school, reading some educational books and journals, and one of them chose to continue his study in university. All 
of the participants argued that their professional activities are effective in developing their teaching skills. However, for the most useful professional development activity, most of the teachers chose teaching practice or peer teaching. According to them, teaching practice or peer teaching gives them an opportunity to use various methods, directly contact and communicate with the students. Thus, they can evaluate and reflect their teaching directly.

The government provides teachers' group such as MGMP, KKG, and PKG. Twelve of fifty participants join MGMP. Twenty nine of them do not join any English teacher groups, and only one teacher who joins English teacher that is not provided by the government, namely debate English group. According to the teachers who join MGMP, MGMP could help them in improving their teaching skill. By joining this group, they can share their teaching experiences, ideas, new information; and discuss teaching problem, syllabus, curriculum, and government policies.

Besides MGMP, KKG, and PKG, the government also provides the other programs such as seminar, workshop, training, and PLPG. Most of the teachers ever joint training such as curriculum 2013 training, national examination training, and socialization block grant MGMP, even one of them ever joint teacher training in Australia. They have not only join some trainings, but also seminars and workshops. Then, ten of them ever join PLPG. Besides, the teachers also join seminar, workshop, and training that are provided by other departments, such as school and university.

According to the participants, joining government programs can help them to fulfil their needs to develop their professions. They can gain information about how to be a professional teacher, teaching methods, pedagogical knowledge, and curriculum knowledge; share ideas, teaching suggestions, teaching problems and solutions; answer their doubt in teaching; and have a network and experiences.

Then, to gain more teachers' perspective on government programs, the researcher interviewed ten of the participants, six of them are junior high school teachers and the others are senior high school teachers. Based on the interview, these four teachers have different perspectives. Here are some example of their comments:

The first teacher:

“Actually, I still do not know the useful of MGMP, because I am a new member in this group. I join this group because my principle told me that I was registered in MGMP. They do not ask me and only said that I was registered.............. because I am a new teacher, I just ever join a training from my school, it is called inhouse training, so we 
discuss and share each other about our problems in the class, and how to use strategies and methods with colleagues."

The second teacher:

"I also ever join PLPG. It was very useful. I can get much information about teaching. But, because I am lack in some requirements, so I only joined it one day. And I still don't join MGMP or other programs........ because the place for MGMP is too far from my school. I am sure that joining this group will be beneficial, because we can share our problems in the class; we discuss it and get the solutions. We also can share new information, teaching methods etc. As long as I am a teacher in this school, and you know I am only the English teacher in this school, I don't have any friend to discuss my problem in the class, or only share whether this method or strategy is good. So I just try to compare the strategy by using different strategies in different class with same material. I will be very happy if MGMP place is near from my school. And you know, my school is in the uptown, in here the students do not really interested in learning English, may be it because they do not see the function of this language, of course it was very different with the students who live in the city. I always motive them, I say English is easy and many things, but it just works with one student."

The third teacher:

"It was many years that MGMP that I joined don't exist anymore. That time we have planned everything like the schedule of MGMP time and place. So the place for doing MGMP will be different every month, this month will be in this school, next month in the other school, just like we take turns. If it runs well, I think it will be very useful. We can share our ideas, get suggestion; discuss our problem in the class and together we find the solution and I ever join PLPG. It was very useful. I got much information, teaching methods and strategies......... About the teachers become do not excited as how excited they after the training, it happen because when we were in training, the students were our own friends. Of course our friends would pretend to be our students in the class. They asked the questions, they answered our questions. It seems very nice. But when we back to the school, the students were our students. They didn't do what our friends do in the training. They keep silent when I ask them, and no one asks when I 
said any question. Of course it makes us upset. That's way, the teachers who are very excited after training come back to be how they in their daily teaching."

The fourth teacher:

"I ever join MGMP, PLPG and West Java Professional teacher. It is useful, but honestly I prefer to not join it. You know, I have taught more than fifteen years. So I give the chance to the novice teachers, they are still young and need more experiences. For me teaching is not only teaching. We also have to become friends for our students, becomes mother or father for them. And I think the professional teachers will not leave their students. If I join, you know, such this group, of course I need to spend my time in it. I prefer to use this time to prepare my material. Use the time to teach my students. I was ever offered to join training for three months in Australia. It seems to be nice of course. But if I go, it means I leave my students. I don't like it. And you also know that my school is favorite school, my students also excited in learning English, so why I need to leave them?.........About that, according to me it is true. For example training about curriculum 2013, how many times we join the training, the discussions are almost same. And about the teachers who come back to their daily teaching, it because if we join any training or seminar, at the end these activities always discuss about administration. How to make a lesson plan, how to make it, make that. All about administration. A teacher has many things to be prepared for their teaching. And teaching itself, according to me, focuses on how to teach the students, not about administration. This administration makes me sick."

According to the participants, the teachers have a positive perspective on government programs in developing their professionalism. This finding is relevant to Suwarno's (2009) research finding in which the teacher's PKG is important in improving their teaching skill. However, the participant suggest that the government programs will be better if they do not only discuss about administration, but more focus on how to help the teachers improve their teaching skill. Then, the government needs to be paid more attention to the teachers who teach in the villages since the lack of information and facilitation.

According to the teachers' arguments, the most useful professional development activity is teaching practice. By teaching practice, they can evaluate and reflect their teaching 
directly. It is opposite with what Shoqair and Shaaban (2013) in their research that teachers' in Gaza commonly uses action research continually in developing their professionalism.

According to the background of this research that government programs are less effective in helping teacher's professional development, and the teachers only excited in twothree weeks after training, but after that they came back to their daily teaching ways, it is suitable with the teachers' comment in interview. However, it happens because the students in the training are teachers' colleagues that are exactly different with teachers' students in their schools. Then, the teachers prefer to use their time in teaching than wrestle the administration.

All in all, the teachers argued that professional development is important. They also have a positives perspective on doing professional development and also on the teacher professional development programs that are provided by government.

\section{CONCLUSION}

The present study was conducted to find the Indonesian EFL teachers' perspective on government professional development programs due to an opinion that government professional development programs do not efficiently work on helping the EFL teachers improve their professionalism.

The findings show that the EFL teachers have positive perspective in improving their professionalism which is proven by their argument on professionalism definition, the important of professionalism and the activities that they do to improve their professionalism. According to these teachers, peer teaching or teaching practice is the best way in improving their teaching skills. Besides, the EFL teachers also have positive perspective on government professional development programs (MGMP, KKG, and PKG), although few of them suggest that it is better if the government professional development programs focus on improving the EFL teachers' teaching skill than merely discuss administration.

\section{REFERENCE}

Alwasilah, C. (2009). Pokoknya Kualitatif. Bandung: Pustaka Jaya.

Avalos, B. (2011). Teacher professional development in Teaching and Teacher Education over ten years. Teaching and Teacher Education, 27, 10-20. 
Banilower, E. R., Heck, D. J., \& Weiss, I. R. (2007). Can professional development make the vision of the standards a reality? The impact of the national science foundation's local systemic change through teacher enhancement initiative. Journal of Research in Science Teaching, 44, 375-395. doi:10.1002/tea.20145

Brown, H. D. (2001). Teaching by Principles. An Interactive Approach to Language Pedagogy. NY: Longman.

Chatib, M. (2009). Sekolahnya manusia. Bandung: Mizan Pustaka.

Clandinin, D.J., Schaefer, L., Long, J.S., et al. (2013). Teacher education: A question of sustaining teachers. In Zhu, X., \& K. Zeichner (Eds.), Preparing teachers for the 21st century (pp. 251-262). Berlin: Springer.

Danim, S. (2011). Pengembangan profesi guru dari pra-Jabatan, induksi, ke profesional madani. Jakarta: Kencana Prenada Media Group.

Day, C. (2002). Developing teachers: The challenges of lifelong learning. The Taylor \& Francis E-Library: Available from the British Library database.

Garet, M. S., Porter, A. C., Desimore, L., Birman, B. F., \& Yoon, K. S. (2001). What makes professional development effective? Results from a national sample of teachers. American Educational Research Journal, 38, 915-945.

Gebhard, J. G. (2009). Teaching english as a foreign or second language. USA: The University of Michigan Press.

Hall, G., \& Hord, S. (2006). Implementing change: Patterns, principles, and potholes. Toronto: Pearson Education.

Hargreaves, A. (2013). Push, Pull, and Nudge: The Future of Teaching and Educational Change. In Zhu, X., \& K. Zeichner (Eds.), Preparing Teachers for the 21st Century (pp. 217-236). Berlin: Springer.

Harmer, J. (2007). The Practice of English Language Teaching (4th ed.). England: Pearson.

Heck, D. J., Banilower, E. R., Weiss, I. R., \& Rosenberg, S. L. (2008). Studying the effects of professional development. Journal for Research in Mathematics Education, 39, 113152.

Hoque, K. E., Alam, G. M., \& Abdullah, A. G. K. (2011). Impact of teachers' professional development on school improvement- An analysis at Bangladesh standpoint. Asia Pacific Educ, 12, 337-348.

Kane, T. J., \& Cantrell, S. (2010). Learning about teaching: Initial findings from the measures of effective teaching project. Seattle, WA: Bill \& Melinda Gates Foundation.

Khalifah, M., \& Khutub, U. (2009). Menjadi guru yang dirindu: Bagaimana menjadi guru yang memikat dan profesional. Surakarta: Ziyad Visi Media. 
Lee, O., Karen A., Jaime MR., Scott L., Constance T., \& Kathryn LR. (2008). Teachers' perspective on a professional development intervention to improve science instruction among english language learners. J Sci Teacher Educ, 19, 41-67.

Malik, S. R. \& Hamied, F. A. (2014). Research methods: A guide for first time researchers. Bandung: UPI Press.

McDonough, J. \& McDonough, S. (2006). Research Method for English Language Teachers. London: Hodder Headline group.

McNamara, D. (2002). Classroom pedagogy and Primary Practice. NY: Routledge.

Merriam, S. B. (2002). Introduction to Qualitative Research. San Francisco: Jossey-Bass.

Mitchell, K. J, David Z. R., Barbara S. P. \& Kaeli T. K. (2001). Testing Teacher Candidates The Role of Licensure Tests in Improving Teacher Quality. Washington, DC: National Academy Press.

Mohanan, K. P. (2005). Teaching as Facilitating Learning. CDLT (Centre for Development of Teaching and Learning). Retrieved on January 2, 2015 from:http://www.cdtl.nus.edu.sg/publications/assess/teach.htm

Murray, D. E. (2011). What English Teacher Need to Know. New York: Routledge.

Mustofa. (2007). Upaya Pengembangan Professionalisme Guru di Indonesia. . Jurnal Ekonomi \& Pendidikan, 4(1), 76-88.

Noordewir, S., Korthagen, F., \& Zwart, R. C. (2009). Promoting Quality From Within: Towards a New Perspective on Professional Development and Changes in School Culture. the EARLI Conference. Amsterdam: Spring.

Nunan, D. (1996). The Learner-centred Curriculum. USA: Cambridge University Press.

Peraturan Menteri Pendidikan dan Kebudayan Republik Indonesia Nomor 62. (2013). Tentang sertifikasi guru dalam jabatan dalam rangka penataan dan pemertataan guru. Jakarta: Menteri Pendidikan dan Kebudayaan.

Peraturan Menteri Pendidikan Nasional Nomor 16. (2007). Tentang Standar Kualifikasi Akademik dan Kompetensi Guru. Jakarta: Direktorat Jendral Pendidikan Tinggi.

Purnomo, M. T., (2015). Hubungan Keikutsertaan Guru dalam MGMP Bahasa Inggris dengan Kompetensi Professionalisme Guru Mata Pelajaran Bahasa Inggris SMP/MTS se Kecematan Purwakarta. Yogyakarta: Univeristas Negeri Yogyakarta.

Richards, J. C., \& Thomas S. C. F. (2005). Professional Development for Language Teachers Strategies for Teacher Learning. UK: Cambridge University Press.

Rugaiyah, \& Sismiati, A. (2011). Profesi kependidikan. Bogor: Ghalia Indonesia.

Russ, R.S., Sherin, B.L., \& Sherin, M.G. (2016). What Constitutes Teacher learning? In Gitomer, D.H., \& C.A. Bell (Eds.), Handbook of Research on Teaching (pp. 391-438). 5th Edition. Washington, DC: AERA. 
Sheppard, B. et al. (2099). School District Leadership Matters Studies in Educational Leadership. Springer Science+Business Media B. V., 8, 85-100.

Shoqair, M. S. A., \& Shaaban, S. S. A. (2013). Strategies of Professional Development for EFL and Technology teachers. Education Journal, 2(6), 249-255.

Sujanto, B. (2007). Guru Indonesia dan perubahan kurikulum mengorek kegelisahan guru. Jakarta: Sagung Seto.

Suwarno. (2009). Peranan Pusat Kegiatan Guru (PKG) SD dalam Peningkatan Professionalism Guru pada Pembelajaran IPS Sejarah. Surakarta: Univeristas Sebelas Maret.

Tabatabaee-Yazdi, M., Motallebzadeh, K., Ashraf, H., \& Baghaei, P. (2018). Continuing Professional Development Strategies: A Model for the Iranian EFL Teachers' Success. SAGE Open. https://doi.org/10.1177/2158244018764234

Thompson, J. G. (2007). The First-year Teacher's Survival Guide Ready-to-use strategies, Tools \& Activities for Meeting the Challenges of Each School Day (2nd ed.). San Francisco: Jossey-Bass.

Undang-undang Republik Indonesia Nomor 14. (2005). Tentang Guru dan Dosen. Jakarta: Presiden Republik Indonesia.

Vries, S. D., Grift, W. J. C. M. V. D., \& Jansen, E. P. W. A. (2013). Teachers' Beliefs and Continuing Professional Development. Journal of Educational Administration, 51(2), 213-231. 